\title{
Dining Patterns And Physical Activities With Obesity Events In Household Mothers In Taccorong Village, Gantarang District
}

\author{
Nurazisah ${ }^{1}$, A.Nurlaela Amin ${ }^{2}$, Muriyati ${ }^{3}$ \\ S1 Nursing Study Program, Stikes Panrita Husada Bulukumba, Indonesia ${ }^{1}$ \\ Departemen Community and Family Nursing, Stikes Panrita Husada Bulukumba, Indonesia ${ }^{2}$ \\ Departemen Mental Health Nursing, Stikes Panrita Husada Bulukumba ,Indonesia ${ }^{3}$
}

Corresponding Autor : Muriyati.stikes@gmail.com

\begin{abstract}
Based on the preliminary survey researchers the number of obesity increased from March and April to May and June 2018. From the results of research conducted by researchers, more eating patterns are less good than good diet and more who do less physical activity than moderate and heavy physical activity. This study aims to determine the relationship between diet and physical activity with the incidence of obesity in housewives in the Taccorong Village, Gantarang District. This study uses an analytical design with a cross-sectional approach. Sampling was done by purposive sampling technique. The population in this study were 1011 people. The sample in this study were 47 respondents. Data analysis using the Chi-square test on diet and using the Kolmogorov Smirnov test on physical activity. The results of the analysis of diet with obesity using the chi-square test obtained the value $(p=0.000)$ indicating that there was a significant relationship between diet and the incidence of obesity in housewives in Taccorong Village. Whereas physical activity analysis with obesity using Kolmogorov Smirnov test obtained values $(p=0.022)$ showed that there was a relationship of physical activity with the incidence of obesity in housewives in the Taccorong Village. The conclusion of this study is that there is a relationship between diet and physical activity with the incidence of obesity in housewives in the Taccorong Village, Gantarang Subdistrict, Bulukumba District. It is recommended for housewives to behave in a healthy life by maintaining a good diet and regulating physical activity well in order to avoid various degenerative diseases due to complications from obesity. For Bontonyeleng health centers to be able to form cadres to detect total obesity. For the next researcher who uses food recall 24 hours if using repeated time.
\end{abstract}

\section{Keywords: Diet, Physical Activity, Obesity}

\section{INTRODUCTION}

Obesity is a condition where body fat is in excessive amounts (Muriyati \& Syamsuddin $A B, 2018)$. Obesity is a risk factor for the 5th cause of death in the world. Around 2.8 million people in the world die from complications of obesity, 23\% suffer from ischemic heart disease, and $7 \%$ to $41 \%$ have a risk of getting cancer in certain organs (Nugroho, Mulyadi, \& Masi, 2016).

In (2016), WHO explained that obesity kills more people than malnourished people.

More than 1.9 billion adults aged 18 years and over are obese in the world population living in developing countries including Indonesia (WHO, 2016). 
The results of Riskesdas (2007) showed that the prevalence of obesity for South Sulawesi was $16.3 \%$. $11.5 \%$ for men and $20.3 \%$ for women. Whereas in 2015 , the prevalence of obesity was $25.51 \%$ based on sex. Men are $24.15 \%$ and women are $26.63 \%$. So it can be concluded that the prevalence of obesity in South Sulawesi is more experienced by women (Health Profile of South Sulawesi Province, 2016).

The prevalence of obesity by sex in the District / City in (2014), Makassar City as many as 344 people. 114 men and 230 women (Makassar City Health Profile, 2014). Whereas in Bulukumba Regency in (2016), the prevalence of obesity was 913 people (49.3\%). 115 men (7.21\%), 798 women (50.03\%) collected from several puskesmas. The highest prevalence is in the working area of Bonto Bahari Puskesmas as many as $425(44.6 \%)$ and the lowest in the Caile Puskesmas working area is 38 people (36.54\%). There are 13 puskesmas that have not collected obesity data, one of which is the Bontonyeleng Community Health Center (Bulukumba City Health Office, 2016). Based on a preliminary survey conducted by researchers on housewives in Taccorong Village (2018), the results of measurements of height and weight in 87 housewives found 64 people who were categorized as obese with childbearing age (15-49) years, 7 people obesity category above 49 years of age and 16 people overweight category with 1011 mothers (52.82\%). The purpose of this study was to determine whether there is a relationship between eating patterns and physical activity with the incidence of obesity in housewives in Taccorong Village, Gantarang District, Bulukumba Regency in 2018.

\section{MATERIAL AND METHODS}

This research was conducted in Taccorong Village, Gantarang District, Bulukumba Regency. The research design used in this study is an analytic design with a Cross Sectional approach (Notoatmodjo, 2012), which aims to determine the relationship of eating patterns and physical activity with the incidence of obesity in housewives in Taccorong Village, Gantarang District, Bulukumba Regency. Population is the whole object of research or object under study (Notoatmodjo, 2012). The population in this study were all housewives in Taccorong Village, Gantarang District, Bulukumba Regency, amounting to 1011 (52.82\%). Samples are objects that are studied and are considered to represent the entire study population (Notoatmodjo, 2012). The sample in this study were housewives who were obese in Taccorong Village, Gantarang District, Bulukumba Regency who met the criteria of 47 respondents. 
The instruments used in this study consisted of 2 types, namely using 24-hour food recall sheets to determine dietary patterns and daily activity form sheets to determine physical activity. Data were analyzed based on measuring scale and research objectives using computerized program software. Data were analyzed by: (1). Univariate Analysis, Analysis is done to see the proportion. (2). Bivariate Analysis, Bivariate Analysis is an analysis to find out the interaction between two variables (Saryono, 2013). The statistical test used was the chi-square test on dietary variables and the KolmogorovSmirnov test on physical activity variables. The confidence interval taken was $95 \%$ and the accepted significance limit if $\mathrm{p}<0.05$.

\section{RESULTS}

Table 1. Frequency Distribution Based on Characteristics of respondents

\begin{tabular}{|c|c|c|}
\hline Frequency & n & Persentage (\%) \\
\hline \multicolumn{3}{|l|}{ Age } \\
\hline Young Adult & 25 & 53,2 \\
\hline Elderly & 22 & 46,8 \\
\hline \multicolumn{3}{|l|}{ Level of Education } \\
\hline Primary School & 23 & 48,9 \\
\hline Middle Education & 11 & 23,4 \\
\hline High Education & 12 & 25,5 \\
\hline Bachelor & 1 & 2,1 \\
\hline Amount & 47 & 100,0 \\
\hline \multicolumn{3}{|c|}{$\begin{array}{l}\text { Based on (Table } 1 \text { ) shows that most of the age of the respondents are in the } \\
\text { category of young adults as many as } 25 \text { respondents }(53.2 \%) \text {, more respondents in } \\
\text { elementary education are } 23 \text { respondents }(48.9 \%) \text {. }\end{array}$} \\
\hline \multicolumn{3}{|c|}{$\begin{array}{l}\text { Table 2. Frequency distribution of respondents based on diet, physical activity and } \\
\text { obesity. }\end{array}$} \\
\hline Frequency & $\mathrm{n}$ & Percentage (\%) \\
\hline \multicolumn{3}{|l|}{ Dietary habit } \\
\hline Well & 23 & 48,9 \\
\hline Not good & 24 & 51,1 \\
\hline \multicolumn{3}{|l|}{ Physical activity } \\
\hline Light & 33 & 70,2 \\
\hline Is & 12 & 25,5 \\
\hline Weight & 2 & 4,3 \\
\hline \multicolumn{3}{|l|}{ Obesity } \\
\hline Obesity 1 & 23 & 48,9 \\
\hline Obesity 2 & 24 & 51,1 \\
\hline Amount & 47 & 100,0 \\
\hline
\end{tabular}

Based on (Table 2) shows the distribution of the number of respondents based on diet, physical activity and obesity. Most respondents ate in the poor category as many as 
24 (51.1\%), while at least the respondents in the good category were 23 respondents (48.9\%). The most physical activity in the mild category were 33 respondents $(70.2 \%)$, while the least in the heavy category were 2 respondents (4.3\%). And obesity more in the category of obesity 2 as many as 24 respondents (51.1\%), while fewer in the category of obesity 1 as many as 23 respondents (48.9\%).

Table 3. Relationship between Diet and Physical Activity and the Occurrence of Obesity

\begin{tabular}{|c|c|c|c|c|c|c|}
\hline \multirow{3}{*}{ Dietary Habit } & \multicolumn{4}{|c|}{ Obesitas } & \multirow{3}{*}{ Total } & \multirow{3}{*}{$P$} \\
\hline & \multicolumn{2}{|c|}{ Obesity one } & \multicolumn{2}{|c|}{ Obesity two } & & \\
\hline & $\mathrm{N}$ & $\%$ & $\mathbf{n}$ & $\%$ & & \\
\hline Good & 21 & 91,3 & 2 & 8,7 & 23 & \multirow{2}{*}{$0,000^{*}$} \\
\hline Not Good & 2 & 8,7 & 22 & 91,7 & 24 & \\
\hline \multicolumn{7}{|c|}{ Physical Activity } \\
\hline Light & 11 & 47,8 & 22 & 91,7 & 33 & \multirow{3}{*}{$0,022^{*}$} \\
\hline Moderate & 10 & 43,5 & 2 & 8,3 & 12 & \\
\hline Severe & 2 & 8,7 & 0 & 0,0 & 2 & \\
\hline Amount & 23 & & 24 & & 47 & \\
\hline
\end{tabular}

Based on (Table 3) shows the relationship between eating patterns and the incidence of obesity in housewives in Taccorong Village, from 47 respondents included in the good eating category as many as 23 respondents or approximately (48.9\%), while those included as poor eating patterns were 24 respondent or around (51.1). The results of SPSS analysis using the chi square test obtained $p$ value $=0,000<0.05$. So it can be concluded that there is a significant relationship between diet and obesity.

The relationship of physical activity with the incidence of obesity in housewives in Taccorong Village, from 47 respondents included in the category of light activity as many as 33 respondents or approximately (70.2\%), moderate activity as many as 12 respondents or approximately (25.5\%), and activities weight of 2 respondents or around (4.3\%). The results of the SPSS analysis using the Kolmogorov Smirnov test obtained a value of $\mathrm{p}=0.022<0.05$. So it can be concluded that there is a relationship between physical activity and the incidence of obesity

\section{DISCUSSION}

In this study it was seen that there was a significant relationship between eating patterns and physical activity with the incidence of obesity in housewives in Taccorong Village, Gantarang District, Bulukumba Regency. From the Chi Square test results obtained $p$ value $=0,000(p<0.05)$, it can be concluded that there is a significant relationship between diet and the incidence of obesity. This is in line with the results of Evan's research, Wiyono Joko, 
Candrawati Erlisa (2017), the results show there is a relationship between eating patterns and the incidence of obesity with a value of $\mathrm{p}=0.004$.

Researchers argue that diet is very closely related to the incidence of obesity because most obese sufferers have a poor diet in the obesity category 2 such as eating lots of oily food every day, milking but consuming less fruit. When someone consumes excessive fatty food, it will be buried in the body due to lack of fat burning and then obesity occurs. Based on the results of the study using the Kolmogorov Smirnov statistical test obtained $\mathrm{p}$ value $=0.022(\mathrm{p}<0.05)$, it can be concluded that there is a relationship of physical activity with the incidence of obesity. In line with the results of the study, Nurul, Santoso \& Utamy (2018) found that there was a significant relationship between physical activity and the incidence of obesity with a value of $p=0.039$.

Researchers argue that physical activity is closely related to the incidence of obesity, especially mild physical activity. Physical activity of housewives who are obese more light physical activities in the category of obesity 2 such as cooking, sitting a lot, sleeping, and watching tv. So they are more at risk of developing degenerative diseases due to obesity because of lack of balance with exercise. Though it is known that exercise can provide benefits such as increasing the body's metabolism to prevent obesity and maintain ideal body weight, reduce the risk of various diseases such as high blood pressure, coronary heart disease, diabetes, improve the hormonal system, and increase the body's immune system against diseases

\section{CONCLUSIONS}

Based on the results of the study above, it was concluded that there was a significant relationship between eating patterns and physical activity with the incidence of obesity in housewives in Taccorong Village, Gantarang District, Bulukumba Regency. It is recommended for housewives to behave in a healthy lifestyle by maintaining a good diet and regulating physical activity properly to avoid degenerative diseases due to complications from obesity. For Bontonyeleng health centers to be able to form cadres to detect total obesity. For further researchers who use 24-hour food recalcit if time is used repeatedly to examine dietary patterns.

\section{REFERENCES}

Anata, F. S. (2015). Dietari assessmentof_individual level 24 hous recall. Retrieved September Rabu, 2018, from www.academia.edu: http://www.academia.edu/20206133/dietari_assessment_of_individual_level_2 4_hous_recall_ 
Arisman. (2013). Obesitas, Diabetes Melitus, \& Dislipidemia. Jakarta: Penerbit Buku Kedokteran EGC.

Boediman, D. (2009). Sehat Bersama Gizi. Jakarta: CV Sagung Seto.

Candra Alfianto, Wahyuni D., T., \& Sutriningsih A. (2016). Hubungan aktivitas fisikdan pola makan dengan kejadian obesitas pada remaja di SMA Laboratorium Malang. E.journal kep Vol 1. No 1. 2016.

D.Tilong, A. (2014). Rahasia Pola Makan Sehat. Jogjakarta: FlashBooks.

Dahlan, M. S. (2012). Langka-langkah Membuat Proposal Penelitian Bidang Kedokteran Dan Kesehatan.

Danari, A. L., Mayulu, N., \& Onibala, F. (2013). Hubungan aktivitas fisik dengan kejadian obesitas pada anak sd di kota manado. ejournal keperawatan (e-Kp) Volume 1. Nomor 1. Agustus 2013.

Dharma, K. K. (2015). Metodologi Penelitian Keperawatan. Jakarta: CV. Trans Info Media.

Dinas Kesehatan Kota Bulukumba. (2016). Seksi Pencegahan dan penanggulangan Penyakit. Bulukumba.

Evan, Wiyono Joko, Candrawati Erlisa (2017). Hubungan antara pola makan dengan kejadian obesitas pada mahasiswa di universitas tribhuwana tunggadewi malang

Faridi, a., \& Hidayati, w. (2016). Analisis faktor risiko kejadian obesitas sentral pada ibu rumah tangga di perumahan griya abuan asri desa sukamaju kecamatan labuan kabupaten pandeglang banten .

G.Mokolensang, Olivia, E.Manampiring, Aaltje \&Fatimawali(2016). Hubungan pola makan dan obesitas pada remaja di Kota Bitung.

Harahap, D. U. (2016). Hubungan Pengetahuan Ibu Tentang Obesitas Bali dengan Kejadian Obesitas Pada Balita Di Nagari Koto Rajo Kab. Pasaman. Jurnal Kesehatan Stikes PrimaNusantara Bukittinggi, Vol.7 No.1 Januari.

Isnaini, Sartono, A., \& Winaryati, E. (2012). Hubungan Pengetahuan Obesitas Dengan Rasio Lingkar Panggul Pada Ibu Rumah Tangga di Desa Pepe Krajan Kecamatan Tegowanu Kabupaten Grobongan. jurnal gizi universitas muhammadiyah semarang november 2012, volume 1, nomor 1.

K.Moha, M., Bidjuni, H., \& Lolong, J. (2017). Hubungan obesitas dengan harga diri pada remaja di sman 1 limboto,kecamatan limboto kabupaten gorongtalo. e-journal Keperawatan (e-Kp) Volume 5, nomor 1, Februari 2017.

Kurniawati, Y., Fakhriadi, R., \& Yulidasari, F. (2016). Hubungan pola makan, asupan energi, aktivitas fisik, dan durasi tidur dengan kejadian obesitas pada polisi. Jurnal Publikasi Kesehatan Masyarakat Indonesia, Vol.3 No.3, Desember 2016. 
Kussoy, K., Fatimawali, \& Kepel, B. (2013). Prevalensi obesitas pada remaja dikabupaten mminahasa. Jurnal e-Biomedik (eBM), Volume 1, Nomor 2, Juli 2013.

M.Black, J., \& Hawks, J. H. (2014). Keperawatan medikal bedah. Singapore: Elsevier.

Maidelwita, Y. (2012). Pengaruh faktor genetik, pola komsumsi dan aktivitas fisik dengan kejadian obesitas pada anak kelas 4-6 sd sbi percobaan ujung gurun padang.

Muriyati, \& AB Syamsuddin. (2018). Dasar-dasar Overweight Obesitas Aerobik. Jawa Timur: Wade Group.

Musralianti, F., Rattu, A., \& Kaunang, W. P. (2016). Hubungan antara aktivitas fisik dan polamakan dengan kejadian obesitas padasiswa di smp kristen. Pharmacon jurnal ilmiah farmasi-unsrat vol.5 no.2 mei 2006 isn 230-2493.

Notoatmodjo, s. (2012). Metodelogi penelitian kesehatan. Jakarta: Pt Rineka cipta.

Nugroho, K., Mulyadi, \& Masi, G. N. (2016). Hubungan aktivitas fisik dan pola makan dengan perubahan indeks massa tubuh pada mahasiswa semester 2 programstudi ilmu keperawatan fakultas kedokteran. e-journal Keperawatan(eKp) Volume4 Nomor 2, Juli 2016.

Nurmalina, R. (2011). Pencegahan \& Manajemen Obesitas. Bandung: Alex Media Komputindo.

Nurul, K., Santoso, E. U., \& Utamy, L. W. (2018). Aktivitas fisik dan kejadian obesitas sentral pada wanita di Kelurahan Tanah Patah Kota Bngkulu. CHMK Nursing Scientifc Journal Vol.2 No.1 April.

Profil Kesehatan Kota Makassar. (2014). Retrieved Maret Kamis, 2018, from http://www.depkes.go.id/resources/download/profil/PROFIL_KES_PROVINSI_2 014/27_Sulawesi_Selatan_2014.pdf

Profil Kesehatan Provinsi Sul-Sel. (2016). Retrieved April Kamis, 2018, from Profil Kesehatan Provinsi Sul-Sel:

https://dinkes.sulselprov.go.id/file/publik/Data\%20ProfilL\%202015.pdf

Proverawati, A. (2010). Obesitas dan gagguan perilaku makan pada remaja. Yogyakarta: Nuha Medika.

Proverawati, A., \& Rahmawati, E. (2012). Perilaku hidup bersih dan sehat (phbs). Yogyakarta: Nuha Medika.

Rachmawati , S., \& Sulchan, M. (2014). Asupan lemak dan kadar high density lipoprotein (hdl) sebagai faktor risiko peningkatan kadar c-reactive protein (crp) pada remaja obesitas dengan sindrom metabolik. Journal of Nutrition College, Volume 3, Nomor 3, Tahun 2014.

Riadi, M. (2016, januari selasa). pengertian jenis faktor penyebab obesitas. Retrieved september Rabu, 5, from www.kajianpustaka.com: 
https://www.kajianpustaka.com/2016/01/pengertian-jenis-faktor-penyebabobesitas.html?m=1

Riskesdas. (2007). Retrieved Maret Kamis, 2018, from riskesdas: https://www.google.com/search?client=firefox-b\&ei=NFUFW-

awCIuEvQTAwIPYBg\&q=riskesdas+provinsi+sulsel+2007\&oq=riskesdas+pro vinsi+sulsel+2007\&gs_l=psy-

ab.3...3440.17470.0.18180.65.27.0.11.11.0.260.3624.0j10j8.18.0.......1c.1.64.psyab..37.27.3394...0j0i22i

Saryono. (2013). Metodologi Penelitian Kualitatif Dan Kuantitatif. Yogyakarta: Nuha Medika.

Sjahid, S. I., A.Gurnida, D., \& Kurnia, N. (2001). Hubungan pola makan dan pola aktivitas fisis dengan obesitas pada anak. Jurnal Bionatura, Vol. 3, No. 2, Edisi 1, Juli 2001.

Soegih, R., \& Wiramihardja, K. (2009). Permasalahan Dan Terapi Medis Obesitas . Jakarta: CV Sagung Seto.

Sudaryanto, A., Setiyadi, N. A., \& Frankilawati, A. D. (2014). Hubungan antara pola makan, genetik, dan kebiasaan olahraga terhadap kejadian diabetes melitus tipe ii di wilayah puskesmas nusukan, banjarmasin. Prosiding SNST ke-5 Tahun 2014.

Sundari, E., Masdar, H., \& Rosdiana, D. (2015). Angka kejadian obesitas. JOM FK Volume 2.

Suryaputra, K., \& Nadhiroh, S. R. (2012). Perbedaan pola makan dan aktivitas fisik antara remaja obesitas dengan non obesitas. Makara, kesehatan, vol. 16, no. 1, juni 2012.

Tanto, c., liwang, f., hanifati, s., \& pradipta, e. a. (2014). Kapita selekta kedokteran. Jakarta: media aesculapius.

WHO. (2016). Retrieved Maret Kamis, 2018, from www.who.int: http: //www.who.int/mediacentre/factsheets/fs311/en/

Widiantini, w., \& Tafal, z. (2014). Aktivitas Fisik, Stres, dan Obesitas pada Pegawai Negeri. Jurnal Kesehatan Masyarakat Nasional Vol. 8, No. 7, Februari 2014.

Yulianti, Lilik Noor \& Retnaningsih (2016). Survey Konsumsi Pangan. 